p-ISSN 1693-9484, $e$-ISSN : 2621-8313

Majalah Ilmiah Bahari Jogja (MIBJ)

Vol. 17 No. 2, Juli $2019 \quad$ (98-109)

DOI : 10.33489/mibj.v17i2.214

(C) 2019 Akademi Maritim Yogyakarta

\title{
Impor Gula Mentah (Raw Sugar) Versus Swasembada Gula
}

\author{
Pantja Siwi V R Ingesti ${ }^{1 *}$, Budi Handojo ${ }^{2}$ \\ ${ }^{1}$ Politeknik LPP Yogyakarta, Jl LPP, No. 1A Yogyakarta 55282, Indonesia \\ ${ }^{2}$ Akademi Maritim Yogyakarta, Jl. Magelang KM 4,4, Yogyakarta, Inonesia \\ * Corresponding Author. Email: pantjasiwivri@yahoo.co.id. Telp:+628122724875
}

\begin{abstract}
Abstrak
Gula Kristal Putih (GKP) merupakan komoditas pangan yang dibutuhkan terbanyak kedua setelah beras oleh rakyat Indonesia. Seiring dengan meningkatnya pertambahan penduduk, permintaan akan GKP juga semakin tinggi. Kebutuhan gula nasional dibagi menjadi dua, yaitu untuk konsumsi langsung (rumah tangga) dan kebutuhan tidak langsung (industri makanan, minuman, dan farmasi). Dalam lima tahun terakhir, permintaan gula konsumsi rumah tangga relatif stabil. Sebaliknya, permintaan gula industri semakin meningkat dan secara keseluruhan jauh melampaui kapasitas produksi gula nasional

Beberapa upaya yang dilakukan oleh pemerintah untuk memenuhi kebutuhan GKP saat ini adalah melakukan impor gula dan menyiapkan pencapaian swasembada gula konsumsi rumah tangga dengan target pencapaian tahun 2019. Kebijakan impor gula dengan pencapaian swasembada gula sama-sama berat untuk dicapai karena luas areal tebu dan tingkat produktivitas tebu semakin menurun. Pabrik-pabrik gula peninggalan Belanda harus direvitalisasi sedangkan pembangunan Pabrik Gula (PG) baru akan membutuhkan biaya yang tinggi begitu juga dengan penelitian. Oleh karena itu, upaya yang dapat dilakukan dengan cepat adalah impor gula dengan ketentuan hanya dilakukan untuk memenuhi kebutuhan industri dan dalam bentuk gula mentah (Raw Sugar).
\end{abstract}

\section{Kata Kunci: konsumsi gula, impor gula, swasembada gula}

\begin{abstract}
White Crystal Sugar (GKP) is the second most demanded food commodity in Indonesia after rice. The demand of GKP rises with the increasing population. National demand of sugar comprises of direct consumption (household) and indirect needs (food, beverage and pharmaceutical industries). In the last five years, the demand for sugar in household consumption has been relatively stable. In contrast, the demand for industrial sugar is increasing and the overall demand for sugar surpasses national sugar production.

Efforts made by the government at this time including importing sugar and preparing for the achievement of self-sufficiency in household sugar consumption scheduled for 2019. Implementing both policies are challenging due to the declines in sugarcane fields and productivity. Our Dutch-heritage factories must be revitalized whereas building a new sugar factory $(P G)$ is costly as well as research. Therefore, the effort that can be done quickly is importing sugar for industrial demand in form of raw sugar (Raw Sugar).
\end{abstract}

Keywords: sugar consumption, sugar imports, self-sufficiency sugar 


\section{PENDAHULUAN}

Indonesia dikenal sebagai negara agraris dimana sebagian besar penduduknya mencukupi kebutuhan keluaganya dari sektor pertanian, apakah pertanian tanaman pangan, perkebunan, kehutanan, perikanan dan peternakan. Selain itu Indonsia juga dikenal dengan negra "gemah ripah loh jinawi" yang menjanjikan kesejahteraan bagi rakyatnya. Kondisi inilah yang menjadikan rakyat Indonesia merasa terpenuhi kebutuhannya dengan mudah, tanpa disadari semakin bertambahnya jumlah penduduk semakin bertambah pula permintaan kebutuhan pokok yaitu pangan.

1. Dalam UU Nomor 18 Tahun 2012 tentang pasal 4 tentang penyelenggaraan pangan bertujuan untuk :

2. Pasal 4.a, meningkatkan kemampuan memproduksi pangan secara mandiri,

3. Pasal 4.c, mewujudkan tingkat kecukupan pangan, terutama pangan pokok dengan harga yang wajar dan terjangkau sesuai dengan kebutuhan masyarakat.

4. Pasal 4.e, meningkatkan nilai tambah dan daya saing komoditas pangan di pasar dalam negeri dan luar negeri,

5. Pasal 4.g, meningkatkan kesejahteraan bagi petani, nelayan, pembudi daya ikan, dan pelaku usaha pangan dan melindungi dan mengembangkan kekayaan sumber daya pangan nasional.

Salah satu kebutuhan pangan pokok ketersediaannya selalu harus terpenuhi adalah gula, pada saat ini, gula termasuk komoditas pangan kedua setelah beras. Berdasarkan undang-undang pangan no 18 tahun 2012 maka ketersediaan gula harus tercukupi secara mandiri dengan harga yang wajar dan terjangkau sesuai dengan kebutuhan masyarakat. Selain itu diharapkan gula dapat meningkatkan nilai tambah dan daya saing pangan sehingga petani tebu dapat menikmati peningkatan pendapatan dan yakin bahwa budidaya tanaman tebu memberi keuntungan. Apabila hal ini bisa terwujud maka kesejahteraan petani tebu akan meningkat dan dapat melestarikan kekayaan sumber daya pangan nasional. Menurut data statistic sampai dengan bulan Januari - November 2018 import gula berada diurutan kedua setelah biji gandum yaitu sebesar 4,6 juta ton. Sebagai gambaran berikut disajikan grafik urutan dan jumlah impor komoditas pangan dari bulan Januari - November 20181 di bawah ini. 
Tabel 1. Urutan dan Jumlah Impor Komoditas Pangan Periode Januari November 2018

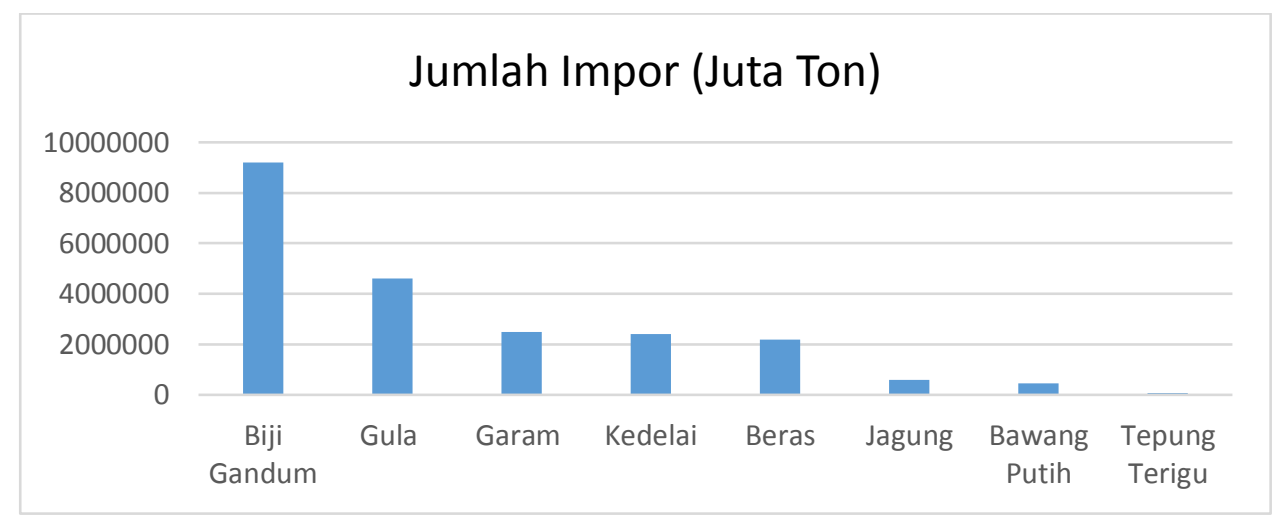

Sumber . https://databoks.katadata.co.id/18 Februari 2019

Grafik 1. Urutan dan jumlah Impor Komoditas Pangan Periode Januari Novenber 2018

Sampai saat ini kebutuhan konsumsi gula tidak seiring dengan produksi gula, konsumsi gula nasional selalu lebih besar dibandingkan produksi gula, baik untuk konsumsi rumah tangga maupun industri makanan, minuman, dan farmasi. Kebutuhan gula untuk konsumsi rumah tangga berupa gula kristal putih (GKP), sedangkan konsumsi untuk industri berupa gula kristal rafinasi (GKR), Lima tahun terakhir permintaan akan gula rumah tangga relatif stabil sedangkan permintaan gula industri mempunyai kecenderungan naik.

Selain faktor pertambahan jumlah penduduk, meningkatnya kebutuhan konsumsi gula juga disebabkan oleh faktor ekonomi yang semakin meningkat. Oleh karena itu permintaan akan produk industri pangan meningkat sehingga permintaan kebutuhan gula industri semakin bertambah.

Pada tabel 1 di bawah ini dapat dilihat gambaran kebutuhan gula nasional bila ditinjau dari peruntukan atau pengkonsumsi dari tahun 2013 sampai dengan 2017.

Tabel 1. Kebutuhan Gula di Indonesia Tahun 2013 - 2017

\begin{tabular}{|l|c|c|c|}
\hline Tahun & $\begin{array}{c}\text { Rumah tangga } \\
\text { (Juta Ton) }\end{array}$ & $\begin{array}{c}\text { Industri } \\
\text { (Juta Ton) }\end{array}$ & $\begin{array}{c}\text { Jumlah } \\
\text { (Juta Ton) }\end{array}$ \\
\hline 2013 & 2,8 & 2,8 & 5,6 \\
\hline 2014 & 2,8 & 2,8 & 5,6 \\
\hline 2015 & 2,9 & 2,9 & 5,8 \\
\hline 2016 & 2,8 & 3 & 5,8 \\
\hline 2017 & 2,8 & 2,9 & 5,7 \\
\hline
\end{tabular}

Sumber : Sumber. databoks.katadata.co.id/datapublish/2017/07/11/2017

Dalam tabel 1 di atas terbukti bahwa total permintaan gula nasional terus meningkat, untuk itu harus dicarikan upaya agar kebutuhan gula bisa terpenuhi 
karena produksi gula nasional belum bisa mencukupi. Berikut ini gambaran distribusi konsumsi gula di Indonesia.

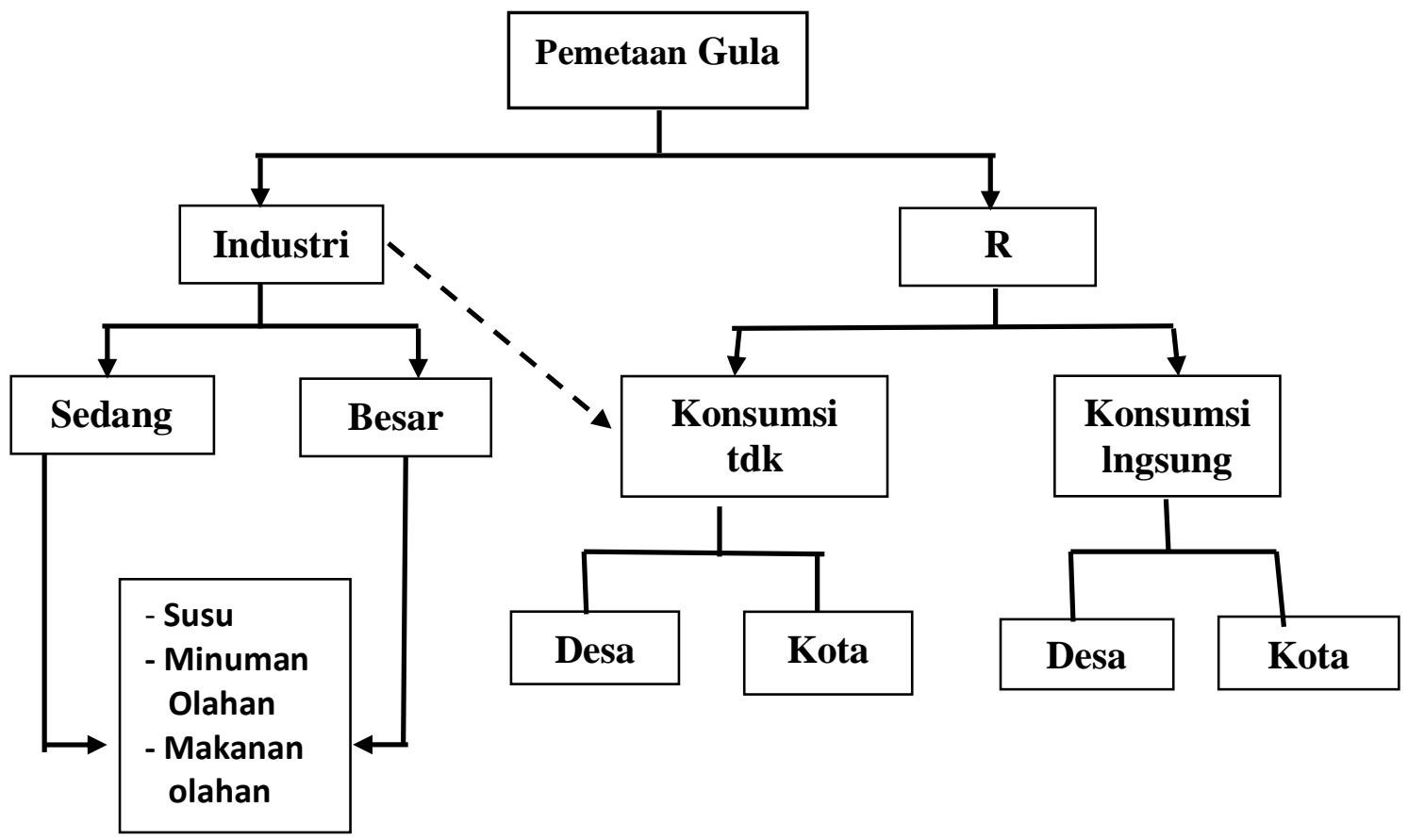

\section{Permasalahan}

Dalam pendahuluan, kebutuhan konsumsi gula nasional dihadapkan pada kondisi permintaan kebutuhan konsumsi gula selalu di atas produksi gula. Oleh karena itu upaya yang dihadapi pemerintah adalah kondisi yang dilematis antara impor gula atau meningkatkan produksi gula melalui peningkatan produktivitas tonase tebu sebagai bahan baku gula. Adapun permasalahan yang dapat diambil adalah :

1. Bagaimana kondisi permintaan dan ketersediaan gula di Indonesia

2. Upaya apa yang dilakukan pemerintah untuk mengatasi pemenuhan kebutuhan gula nasional

3. Apakah pengaruh dari impor gula dan swasembada gula terhadap kehidupan petani.

\section{METODE}

Penelitian ini merupakan Penelitian studi kasus (case study), yang mana proses pengumpulan data dilakukan dengan pendekatan pada kejadian, pendapat dari referensi, serta metode dan teknik dari berbagai sumber informasi

\section{HASIL DAN PEMBAHASAN}

\section{Sentra Wilayah Komoditas Tebu dan Produktivitas Tebu}

Dalam teori ekonomi, untuk menjaga keseimbangan dalam alur kebutuhan pangan masyarkat maka besarnya permintaan dan penawaran barang yang 
dibutuhkan harus seimbang. Dengan demikiaan akan terbentuk suatu kondisi yang stabil dalam memenuhi kebutuhan barang, selain itu juga akan terbentuk harga yang adil.

Kondisi permintaan gula di Indonesia sampai saat ini dalam posisi lebih besar dari gula yang ditawarkn atau ketersediaan gula nasional lebih kecil dibandingkan permintaannya. Oleh karena itu terjadi ketimpangan permintaan gula secara nasional, untuk itu diperlukan suatu upaya untuk memenuhi kekurangan ketersediaan gula nasional. Terdapat tiga pihak yang membutuhkan gula yaitu rumah tangga, industri dan farmasi.

Secara garis besar, produksi gula ditentukan oleh produksi tanaman tebu sebagai bahan baku gula. Pulau Jawa merupakan daerah sentra tanaman tebu bila dilihat dari kriteria luas tanaman, luas panen, produksi, dan jumlah petani tebu. Sedangkan pulau Sumatra juga merupakan sentra tanaman tebu di luar jawa dengan kriteria luas lahan, luas panen, produksi dan jumlah tenaga kerja. Oleh karena itu sejak tahun 2016 pemerintah mulai melakukan penambahan luasan areal lahan tebu seluas 600.000 ha di luar jawa dan akan dilakukan sampai tahun ini (2019) sehingga akan tersedia tambahan luasan areal lahan tebu sebesar 2,4 juta ha. Berdasarkan data dari United States Department of Agriculture (USDA) 2018, produktivitas perkebunan tebu di Indonesia hanya mencapai 68,29 ton per hektar pada 2017. Dengan demikian terdapat tiga permasalahan yang terjadi berkaitan dengan produksi gula yaitu penurunan produktivitas lahan, alih fungsi lahan, alih budidaya ke komoditas selain tanaman tebu dan menurunnya efisiensi di tingkat pabrik.

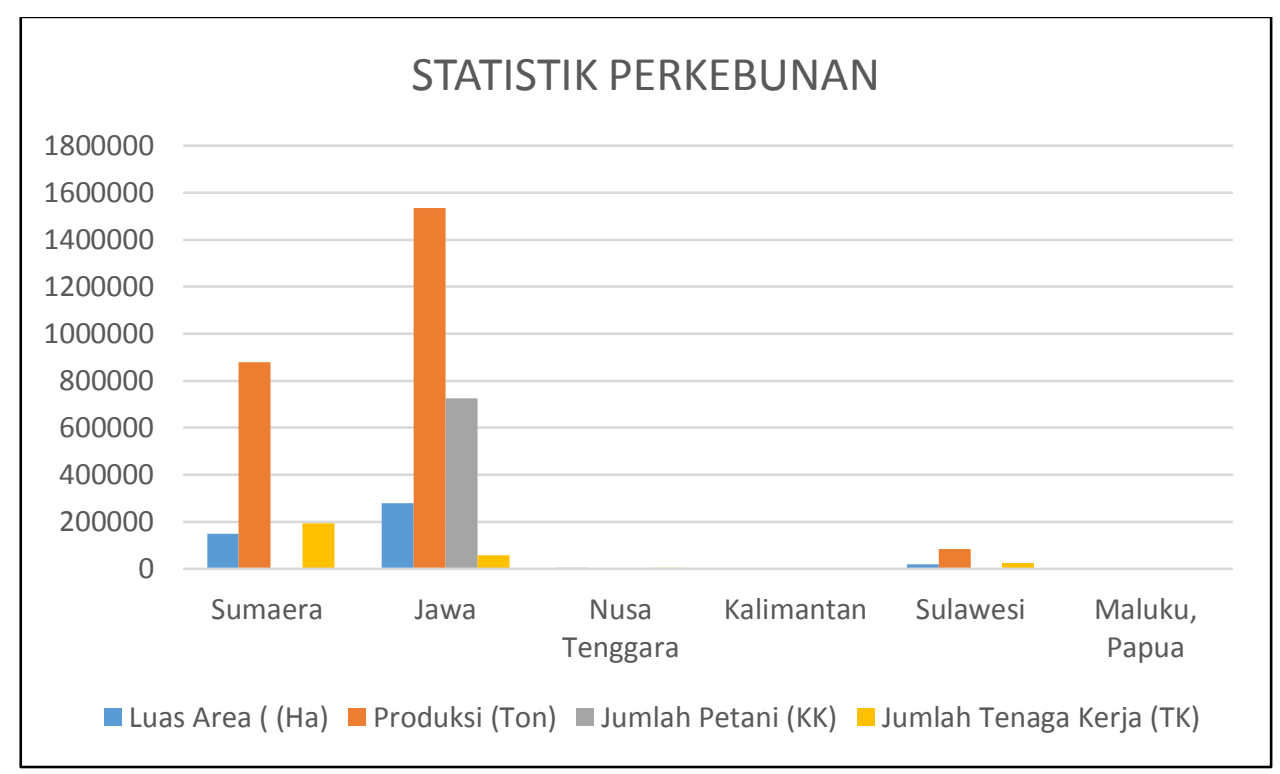

Sumber. ditjenbun.pertanian, Statistik Perkebunan Indonesia tahun 2015-2017 Tebu

Grafik 2. kondisi budidaya tanaman tebu di bebeapa cetra wilayah di Indonesia tahun $2015-2017$ 
Pulau Jawa masih menjadi wilayah andalan untuk tanaman tebu, dilihat dari produksi tebu, luas areal tebu dan jumlah keluarga petani tebu menunjukkan angka yang tinggi dibanding pulau Sumatra, Nusatenggara, Kalimantan, Sulawesi dan Maluku. Yang menjadi kelemahannya di pulau jawa adalah ketersediaan tenaga kerja kurang, sedangkan di Sumatra ketrsediaan tenaga kerja relatif lebih banyak. Dengan demikian ada peluang untuk dibuka penambahan areal lahan dan pembangunan pabrik gula baru di luar jawa, sehingga produktivitas tebu dapat ditingkatkan. Hal ini merupakan salah satu poin dalam kebijakan swasenbada gula.

\section{Upaya Pemenuhan Kebutuhan Gula Nasional}

Kebutuhan gula secara nasional sampai saat ini masih mengalami kekurangan sehingga pemerintah harus berupaya untuk menjamin ketersediaan gula nasional dalam kondisi aman. Dari data yang sudah disampaikan di atas, kekurangan kebutuhan gula terjadi pada tingginya permintaan gula di sektor industri dan farmasi, sedangkan kebutuhan rumah tangga relatif stabil.

Ada dua cara yang sudah dilakukan oleh pemerintah berkaitan dengan pemenuhan kebutuhan gula nasional, yaitu pertama swasembada gula konsumsi yang seharusnya tahun 2019 tercapai dan yang kedua impor gula rafinasi atau gula mentah (raw sugar). kedua cara tersebut mempunyai konsekuensi walaupun keduanya sama-sama bertujuan untuk memenuhi kebutuhan gula nasional.

\section{Swasembada Gula}

Swasembada gula adalah suatu upaya untuk memenuhi kebutuhan konsumsi gula nasional melalui produksi gula yang bersumber dari areal tebu rakyat dan tebu swasta. Pengertian umum swasembada untuk suatu produk disuatu negara akan tercapai apabila secara netto jumlah produk dalam negeri minimal mencapai $90 \%$ dari jumlah konsumsi domestiknya, baik untuk memenuhi konsumsi rumah tangga, industri maupun neraca perdagangan gula nasional. Dengan pengertian tersebut yang dimaksud swasembada gula adalah produksi gula berbasis tebu dalam negeri telah mencapai $90 \%$ dari kebutuhan nasional.

Dalam sistim pergulaan nasional kebutuhan gula dibagi 2 yaitu untuk konsumsi langsung (rumah tangga) dengan kwalitas gula kristal putih (GKP) dan kebutuhan tidak langsung untuk industri makanan, minuman dan farmasi dengan kwalitas gula kristal rafinasi (GKR). Pada tahun 2008 dari pabrik-pabrik gula yang ada (58 PG) produksinya telah memenuhi swasembada gula konsumsi langsung (rumah tangga). Pengembangan selanjutnya diarahkan secara bertahap untuk memenuhi kebutuhan gula industri, baik dengan meningkatkan kwalitas untuk konsumsi industri maupun untuk bahan baku pabrik gula rafinasi.

Tujuan Program Swasembada Gula

- Memenuhi kebutuhan gula nasional secara keseluruhan, baik untuk konsumsi langsung maupun industri;

- Mendayagunakan sumberdaya/aset secara optimal berdasarkan prinsip keunggulan kompetitif wilayah dan efisiensi secara nasional;

- Meningkatkan kesejahteraan petani/ produsen dan stakeholder lainnya;

- Memperluas kesempatan kerja dan peluang berusaha dikawasan pedesaan, sehingga secara nyata berdampak positif terhadap pemberantasan kemiskinan. 
Upaya yang bisa dilakukan oleh Pemerintah untuk meningkatkan produktivitas gula antara lain:

a. Membuat rincian proyeksi produksi nasional, Pada tahun 2015 produksi Gula Kristal Putih (GKP) mencapai 2,95 juta ton. Lalu 2016 mencapai 2,98 juta ton. Kemudian ditahun 2017 sebesar 3,03 juta ton. Pada 2018 sebesar 3,09 juta ton. Terkahir pada tahun 2019 sebesar 3,14 juta ton. Sementara dari proyeksi kebutuhan gula nasional pada tahun 2015. Kebutuhan gula nasional mencapai 5,77 juta ton. Lalu 2016 sebesar 5,97 juta ton naik ditahun 2017 sebesar 6,17 juta ton. Lalu pada tahun 2018 sebesar 6,39 juta ton dan terakhir 6,61 juta ton

b. Penambahan luas areal tebu diarahkan untuk mencapai kebutuhan bahan baku gula sehingga diharapkan produkstivitas gula akan meningkat. Pemerintah akan menyediakan lahan untuk pengembangan tebu seluas 600.000 ha di luar Pulau Jawa setiap tahunnya dan perluasan areal kebun tebu dimulai pada tahun 2016 seluas 600.000 ha sehingga sampai tahun 2019. Sehingga total perluasan areal kebun tebu sebesar 2,4 juta ha.

c. Program peningkatan produksi gula dengan memperluas areal tanaman tebu

d. hanya dapat dilakukan di luar jawa, sedangkan peningkatan produktivitas tanaman tebu dipengaruhi oleh berbagai faktor tidak hanya tipe lahan (sawah/tegalan) tetapi juga penggunaan sarana produksi dan teknik budidayanya. Pemupukan sebagai salah satu usaha peningkatan kesuburan tanah, dengan pemberian pupuk pada tanaman tebu, tebu dapat tumbuh dengan baik dan subur (Hakim, 2008)

e. Pemerintah sampai dengan tahun 2019, mentargetkan penambahan PG sebanyak 11 PG, saat ini sudah ada 4 pabrik gula baru yang sudah terbangun yakni di Blora, Lamongan, Dompu, dan Lampung. Sementara 7 pabrik gula baru lainnya direncanakan terbangun di Sumba Timur, Ogan Komering Ilir, Timor Tengah Selatan, Indramayu, Blitar, Kotawaringin, dan Timor Tengah Utara. (Muhammad Idris, 2017)

f. Revitalisasi berbagai pabrik gula merupakan langkah penting guna meningkatkan produktivitas perkebunan tebu yang terdapat di berbagai daerah di Indonesia. Penurunan produksi gula yang terus menerus terjadi sampai saat ini, diakibatkan faktor-faktor onfarm (cuaca, varietas bibit, pemupukan, dsb) dan faktor-faktor off-farm yaitu mesin-mesin pabrik gula yang sudah tua sehingga produktivitasnya rendah.

g. Pemberdayaan penelitian dan pengembangan dengan menetapkan dana penelitian dan pengembangan sebesar 2,5 persen dari laba bersih masingmasing BUMN gula,

h. Peningkatan kualitas SDM dengan berbagai program pelatihan dan training, dengan sasaran peningkatan produktivitas SDM dan Rencana Aksi (Kementerian BUMN, 2011).

Berdasarkan kajian Hermanto terhadap data produksi GKP tahun 2017 dan 2018 masing-masing mampu memenuhi 72,35 persen dan 67,41 persen jumlah konsumsi. Karena itu, jika merujuk pada kriteria FAO bahwa suatu negara dinyatakan swasembada jika produksinya minimal mencapai 90 persen dari kebutuhan nasionalnya, Hermanto optimistis swasembada bisa diraih lebih cepat. (EH Ismail, 2019). 


\section{Impor Gula Mentah (Raw Sugar)}

Kebutuhan akan permintaan gula nasional sampai saat ini masih belum terpenuhi,

hal ini bisa dilihat dari data produksi dan konsumsi gula bahwa kondisi kebutuhan gula nasional masih lebih tinggi dibandingkan dengan produksi gula nasional. Seperti disebutkan di atas bahwa unsur yang membutuhkan gula yaitu rumah tangga, industri dan lainya. Permintaan gula di tingkat rumah tangga sampai dengan tahun 2018 sudah dapat dipenuhi, akan tetapi untuk industri dan yang lainnya masih kekurangan, oleh karena itu pemenrintah perlu memenuhi kekurangan tersebut dengan malakukan impor gula mentah (Raw Sugar). Dibawah ini gambaran produksi, konsumsi dan impor gula dari tahun 2010 sampai dengan tahun 2017

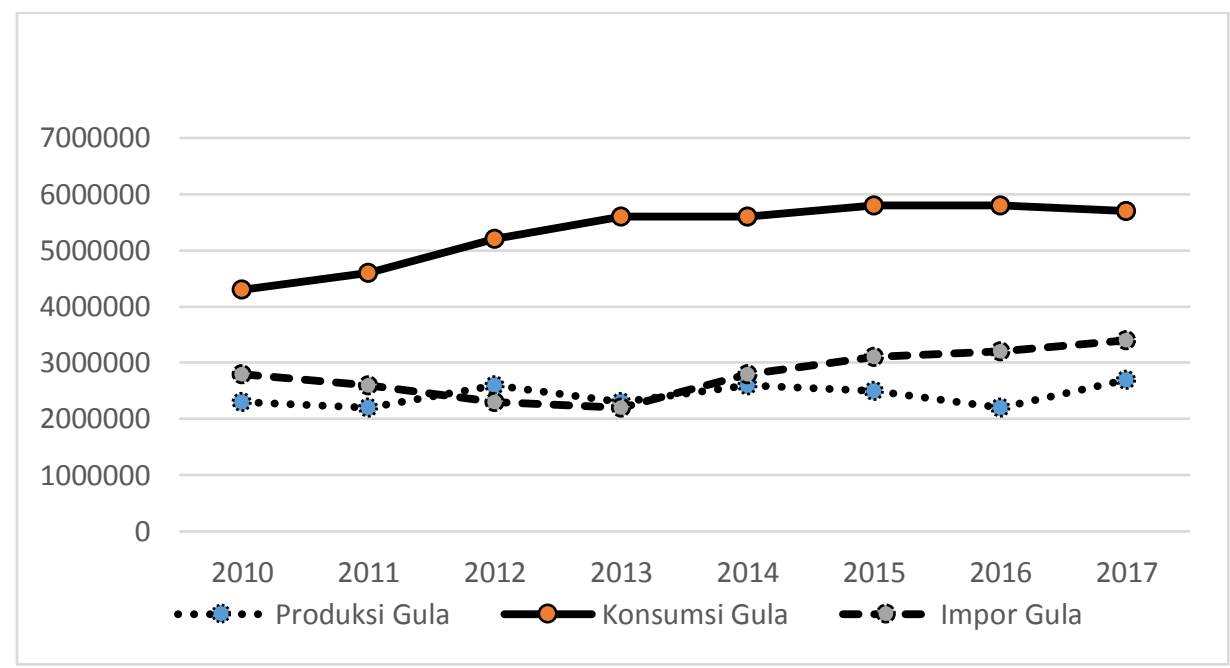

Sumber. databoks.katadata.co.id/datapublish/2017/06/20

Grafik 3. Produksi, Konsumsi dan Impor Gula dari tahun 2010 - 2017

Dari gambaran grafik di atas dapat diketahui terjadi ketimpangan dalam permintaan dan penawaran/ketersediaan gula, Selisih permintaan dan ketersediaan tersebut diakibatkan oleh rendahnya produktivitas tebu yang berpengaruh pada rendahnya rendemen sehingga produksi gula juga rendah. Selain itu kondisi sebagian besar pabrik gula pada saat ini banyak yang tua dan tidak bisa lagi berproduksi secara efisien. Hal ini yang menjadi salah satu dasar pemerintah untuk melakukan impor gula.

Pemerintah melalui Kementerian Perdagangan telah membuka keran impor gula yang masuk pada September 2018. Pelaksanaan impor berpedoman pada Peraturan Menteri Perdagangan (Permendagri) No.117/M-DAG/ PER/12/2015. Berdasarkan Peraturan Menteri tersebut, gula yang diperbolehkan untuk diimpor adalah gula kristal mentah/gula kasar, gula kristal rafinasi, dan gula kristal putih. Pada bulan Januari 2018, Kemendag telah menerbitkan izin impor gula mentah sebesar 1,8 juta ton. Impor tersebut ditujukan sebagai bahan baku untuk industri gula kristal rafinasi (GKR) dari total alokasi sebesar 3,6 juta ton tahun ini. 
Kebijakan impor gula tidak boleh bertentangan dengan Undang-Undang Republik Indonesia no 18 tahun 2012 tentang pangan. Setiap keputusan yang berkaitan dengan impor gula harus ditetapkan sesuai dengan peruntukannya dan juga ketepatan dalam memproyeksikan kebutuhan gula. Hal ini dimaksudkan agar tidak merugikan petani karena apabila impor gula rafinasi yang kemudian diolah oleh pabrik untuk dijadikan gula kristal putih yang seharusnya dialokasikan untuk industri beralih peruntukan dan masuk ke pasar gula konsumsi rumah tangga maka jumlah gula yang ada di pasar rumah tangga menjadi lebih besar dibandingkan permintaan rumah tangga. Inilah yang akan merusak harga gula sehingga HPP gula menjadi turun dan ini akan merugikan petani tebu.

Ketua Umum Asosiasi Petani Tebu Rakyat Indonesia (APTRI) mengungkapkan BEP (titik balik modl) untuk harga gula di tingkat petani sebesar $\mathrm{Rp} 10.600,00$ - $\mathrm{Rp} \mathrm{11,600,00} \mathrm{/} \mathrm{kg} \mathrm{dan} \mathrm{harga} \mathrm{lelang} \mathrm{gula} \mathrm{yang} \mathrm{terjadi} \mathrm{hanya}$ dikisaran harga Rp 10.200,00 - Rp 11.500 tentunya masih dibawah harga BEP oleh karena itu petani belum mendapatkan keuntungan. Selain itu harga BEP Rp $11.600,00 / \mathrm{kg}$ dengan syarat rendemennya 7 - 7,7 sedangkan kondisi sekarang rendemen rata-rata hanya 6 sehingga petani merugi dan akibatnya petani malas menanam tebu sehingga impor gula menjadi semakin banyak.

Kebijakan impor gula yang dilakukan pemerintah sebatas untuk memenuhi kekurangan konsumsi gula nasional terutama untuk industri dan yang lainnya. Akan tetapi yang terjadi adalah dalam memproyeksikan kebutuhan gula dari tahun ke tahun selalu tinggi sehingga kran impor gula yang dilakukan sesuai dengan proyeksi tersebut. Akibatnya terjadi kelebihan persediaan gula dan berdampak pada merembesnya gula rafinasi ke pasar konsumsi. Hal ini mengakibatkan harga gula menjadi turun dan juga akan mengganggu kesehatan karena gula rafinasi merupakan gula setengah jadi yang harus diolah dahulu untuk menjadi gula konsumsi yaitu gula kristal putih. Dibawah ini gambaran data untuk proyeksi dan realisasi konsumsi dan produksi gula tahun 2015 - 2018

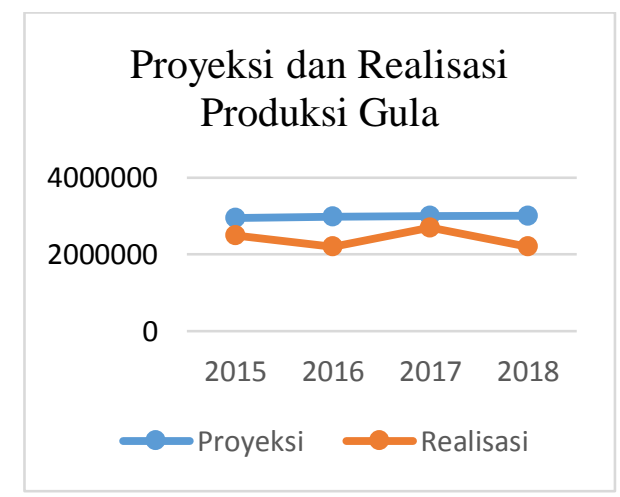

Majalah Ilmiah Bahari Jogja 106 | http://jurnal.amy.ac.id/index.php/MIBJ/ 


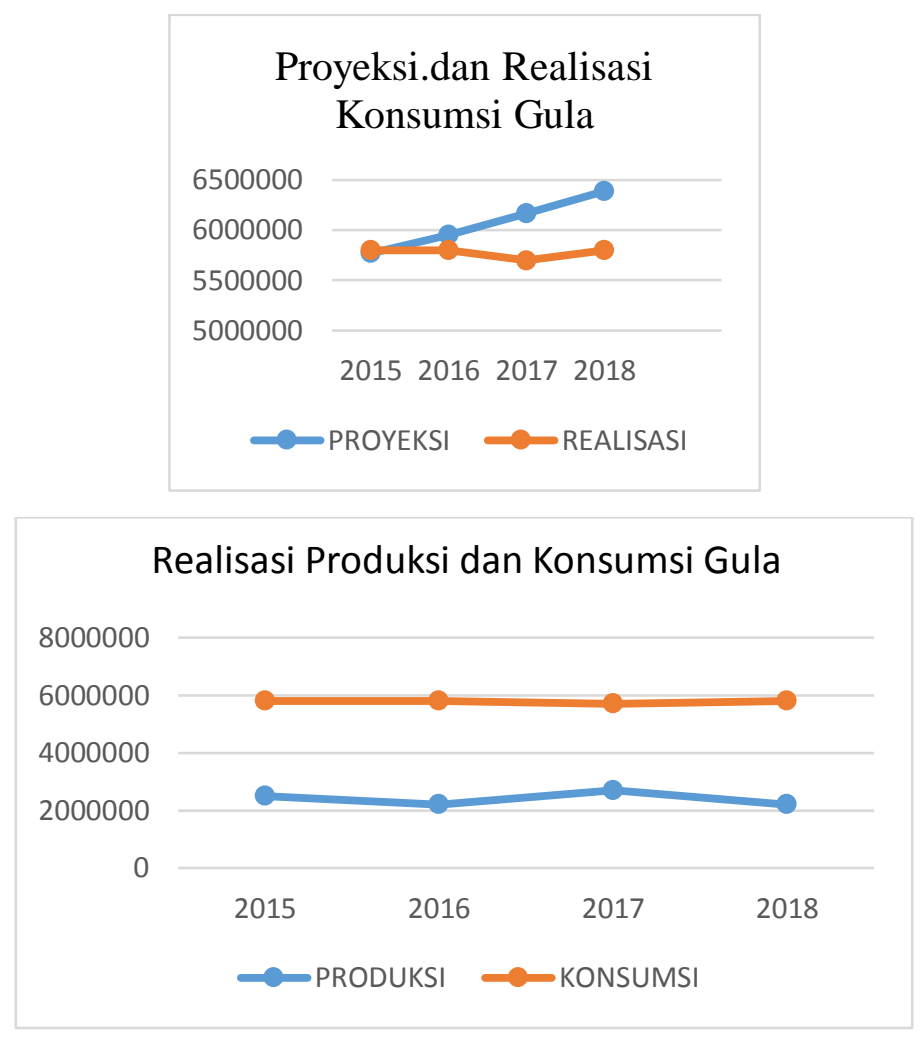

Sumber. databoks.katadata.co.id/datapublish/2017/07/11/2017

Pada grafik proyeksi dan realisasi produksi gula dapat diketahui bahwa realisasi produksi gula dari tahun 2015 sampai dengan 2018 dibandingkan dengan proyeksi produksi lebih tinggi. Dalam hal ini perbandingan antara proyeksi dan realisasi tidak bergitu besar, artinya masih dalam perkiraan yang baik, jadi bisa dipakai sebagai acuan dalam menentukan produksi-produksi tahun berikutnya.

Pada grafik proyeksi dan realisasi konsumsi gula dapat diketahui bahwa realisasi konsumsi gula dari tahun 2015 sampai dengan 2018 dan proyeksi konsumsi lebih tinggi dibandingkan realisasi konsumsi. Hal ini berdampak pada tingginya kekurangan konsumsi gula sehingga angka kekurangan konsumsi gula yang menjadi acuan pemerintah untuk melakukan impor gula. Pada kenyataannya realisasi konsumsi jauh di bawah proyeksi pemerintah sehingga terdapat surplus ketersediaan gula yang akhirnya akan merembes pada pasar konsumsi rumah tangga. Akibat dari surplus ketersediaan gula adalah harga gula dalam negeri menjadi rendah dan apabila ini berlanjut terus maka petani akan alih komoditas diluar tebu yang memberikan harga tinggi dan menguntungkan.

Berdasarkan Permendagri No.117 Tahun 2015, peruntukan gula impor adalah untuk industri, termasuk industri makanan dan minuman, dilakukan oleh perusahaan importir terdaftar dan BUMN. Pasal 22 Peraturan Menteri tersebut dengan tegas mengatakan bahwa importir dilarang untuk: memindahtangankan gula impor kepada konsumen secara langsung dan memperdagangkan impor ke pasar dalam negeri. 
Oleh karena itu perlu ditinjau kembali dasar dari penentuan proyeksi jumlah permintaan dan ketersediaan produksi gula nasional. Penyimpangan yang terjadi pada perhitungan angka proyeksi konsumsi gula yang tinggi berdampak pada angka pengajuan impor gula baik gula rafinasi, gula mentah atau gula konsumsi rumah tangga. Apabila impor gula terus dilakukan dan proyeksinya jauh dari kenyataan maka tujuan dari undang-undang no 18 tahun 2012 tentang pangan tidak tercapai diantaranya upaya memproduksi pangan secara mandiri, nilai tambah dan daya saing gula dipasar dalam negeri menurun, tingkat kecukupan pangan, terutama pangan pokok dengan harga yang wajar dan terjangkau sesuai dengan kebutuhan masyarakat dan tingkat kesejahteaan petani tebu tidak meningkat.

Dampak dari Posisi petani jadi tidak kuat dan gula tidak memiliki daya saing, apabila hal ini terjadi maka petani tidak akan tertarik lagi mengusahakan tebu dan pada akhirnya akan terjadi alih komoditas, petani tidak mau menanam tebu tetapi cenderung memilih komoditas yang memberikan nilai jual yang tinggi. Akibatnya akan kekurangan bahan baku gula, maka kran impor akan dibuka semakin besar dan yang akan diuntungkan adalah pelaku usaha yang memiliki modal besar untuk impor gula.

\section{SIMPULAN}

\section{Kesimpulan}

1. Kebijakan impor gula akan terus terjadi selama produktivitas tanaman tebu rendah, kinerja pabrik gula tidak efisien, proyeksi konsumsi gula jauh diatas realisasi konsumsi gula.

2. Swasembada gula ditujukan untuk memenuhi kebutuhan konsumsi gula nasioal dapat dilakukan diantaranya melalui penambahan areal lahan tebu, revitalisasi pabrik gula dan penambahan jumlah pabrik gula, meningkatkan penelitian yang menghasilkan inovasi berkaitan dengan peningkatan produktivitas tebu serta peningkatan kemampuan dan ketampilan sumber daya manusia melalui pelatihan yang mengarah pada eningkatan produktivitas kerja.

\section{Saran}

1. Dalam rangka penguatan ekonomi petani tebu maka pemerintah harus melakukan kebijakan yang berpihak pada petani diataranya mengurangi nilai impor gula memperpendek rantai pemasaran gula yang bisa menurunkan harga gula.

2. Memperbaiki kondisi pengairan, kesuburan lahan melalui pemberian subsidi pupuk dan obat-obatan sehingga produktivitas tebu jadi meningkat

3. Meningkatkan penelitian terutama yang berkaitan varietas tebu, pengendalian hama dan penyakit

\section{DAFTAR PUSTAKA}

Anonim (2012), Undang-Undang Republik Indonesia tentang Pangan Anonim (2014), Lima arah kebijakan Swasembada gula, https:// industry .kontan .co. 
id/news/ini-lima-arah-kebijakan-swasembada-gula-kementan Minggu, 21 Desember 2014 / diunduh pada tanggal 20 Juni 2019 jam. 15:35 WIB

Anonim (2019), RI Kejar Swasembada Gula 2019 begini jurusnya https://finance. detik.com/industri/diunduh pada tanggal 22 Juni 2019, jam 15.00

Anonim (2019), https://www.republika.co.id/berita/ekonomi/pertanian/19/02/07/ awal, pmjgbx453-kementan-optimistis-capai-target-swasembada-gula-lebih-

Diunduh pada tanggal 22 Juni 2019 jam 20.00

Anonim (2015), http://ditjenbun.pertanian.go.id/berita-202-untuk-mewujudkanswasembada-gula-pemerintah-akan-melakukan-revitalisasi-pabrik-gula. Diunduh pada tanggal 23 juni 2019 jam 14.00

Anonim (2017), databoks.katadata.co.id/datapublish/2017/06/20, diunduh pada tanggal 2 juni 2019 jam 13.00

Anonim (2015), ditjenbun.pertanian, Statistik Perkebunan Indonesia tahun 2015 -2017 Tebu

Anonim (2019), https://databoks.katadata.co.id/18 Februari 2019 diunduh tanggal 25

Juni 2019 jam 20.00 